$3-1-2008$

\title{
Misappropriation of Trademark
}

David W. Barnes

Follow this and additional works at: http://scholarship.law.unc.edu/ncjolt

Cart of the Law Commons

\section{Recommended Citation}

David W. Barnes, Misappropriation of Trademark, 9 N.C. J.L. \& Tech. 171 (2008).

Available at: http://scholarship.law.unc.edu/ncjolt/vol9/iss2/1

This Article is brought to you for free and open access by Carolina Law Scholarship Repository. It has been accepted for inclusion in North Carolina Journal of Law \& Technology by an authorized administrator of Carolina Law Scholarship Repository. For more information, please contact law_repository@unc.edu. 


\section{NORTH CAROLINA JOURNAL OF LAW \& TECHNOLOGY \\ VOLUMe 9, ISSUE 2: SPRING 2008}

\section{MISAPPROPRIATION OF TRADEMARK}

\section{David W. Barnes}

The dominant view of misappropriation doctrine fits trademark law poorly. It is at odds with contemporary theory and the reasons for protecting intellectual property. A more nuanced view of the Supreme Court's germinal misappropriation case leads to a misappropriation doctrine consistent with both externality theory and public goods theory. When viewed this way, IP theory and misappropriation doctrine then lead to rules reflecting a balance between incentive creation and free access. Applying this nuanced interpretation to the issue of Internet initial interest confusion suggests that keyword advertising promotes competition and reduces search costs more than it interferes with incentives to engage in trademarking activity.

\section{INTRODUCTION}

The state law doctrine of misappropriation is based on the idea that people should not reap where they have not sown, that they should not free-ride on the investments of others. ${ }^{2}$ Trademark owners sow investments in their trademarks to reap the resulting goodwill: increased sales brought about by increased renown. If it is a "misnomer to talk of 'misappropriation' of trademarks," as the

\footnotetext{
' Distinguished Research Professor of Law, Seton Hall University School of Law.

${ }^{2}$ A simple view of the elements of such a claim is that the plaintiff has incurred expenses to create something of value, the defendant has profited from that creation without similar expenses, and the plaintiff is damaged. See infra text accompanying note 11 .

${ }^{3}$ J. ThOMAS MCCARThy, 2 MCCARTHY ON TRademarks and UnfaIR COMPETITION $\S 10.72$ (4th ed. 2006). One of the leading authorities on trademark law, J. Thomas McCarthy, observed that:

The misappropriation doctrine cannot be used in ordinary trademark infringement cases as a shortcut around the trademark law's standards of protection. That is, one cannot dispense with the care fully [sic] constructed requirements for trademark protection by blithely claiming
} 
leading trademark authority suggests, reaping another's goodwill should not be enough to support a trademark infringement claim. Courts do, however, rely on this simple interpretation of the misappropriation doctrine in trademark cases. Reaping another's goodwill is sufficient justification in some jurisdictions for finding infringement in Internet initial interest confusion cases. ${ }^{4}$

This Article argues that the "free-riding" view of misappropriation oversimplifies the Supreme Court's germinal misappropriation case, International News Service v. Associated Press. $^{5}$ This simple view is consistent with enjoining Internet keyword advertising, an outcome supported by a recent paper in the North Carolina Journal of Law \& Technology. ${ }^{6}$ A more

that defendant "misappropriated" some symbol of plaintiff which may or may not be capable of trademark protection.

Id. Because it is inappropriate to speak of trademark infringement without demonstrating the usual requirements of consumer confusion about what supplier is the source of a product, "it is a misnomer to talk of 'misappropriation' of trademarks or trade symbols of any type." Id.

${ }^{4}$ See Benjamin Aitken, Keyword-Linked Advertising, Trademark Infringement, and Google's Contributory Liability, 2005 DUKE L. \& TECH. REV. 21, 24 (discussing the contributory liability of search engine providers who aid Internet advertisers). Aitken concludes that search engine providers will be contributorily liable if "the ads ... conceal the advertiser's identity such that the consumer is confused as to the source of the ad, even if just initially." Id. For there to be contributory infringement, there must be direct infringement by the advertiser. See, e.g., Lockheed Martin Corp. v. Network Solutions, Inc., 985 F. Supp. 949, 960-61 (C.D. Cal. 1997) ("Liability for contributory infringement requires that the defendant either '(1) intentionally induces another to infringe on a trademark or (2) continues to supply a product knowing that the recipient is using the product to engage in trademark infringement." (citing Fonovisa Inc. v. Cherry Auction, Inc., 76 F.3d 259, 264 (9th Cir. 1996) (quoting the test set forth in Inwood Labs., Inc. v. Ives Labs., Inc., 456 U.S. 844, 853-54 (1982))). The present article argues that where misappropriation is at issue, there can be no finding of direct infringement on which to base contributory infringement.

${ }^{5} 248$ U.S. 215 (1918).

${ }^{6}$ See Benjamin F. Sidbury, Comparative Advertising on the Internet: Defining the Boundaries of Trademark Fair Use for Internet Metatags and Trigger Ads, 3 N.C. J.L. \& TECH. 35, 60 (2001) ("If the plaintiff can show that the defendant is either (1) using the plaintiff's mark with the intent to usurp the plaintiff's good will (and lure web surfers to defendant's website rather than plaintiff's site) or (2) is acting in bad faith by creating deception as to source or sponsorship, the 
nuanced reading of the Supreme Court's opinion reveals a misappropriation doctrine that is consistent with the leading underlying theories of intellectual property and inconsistent with finding infringement based on initial interest confusion.

This Article compares the overly simple view of misappropriation theory that supports finding infringement in initial interest confusion cases to a more nuanced and accurate view. Internet initial interest confusion cases sometimes involve one supplier including another supplier's trademark in its website's domain name, part of a website's uniform resource locator ("URL") ${ }^{7}$ or hypertext markup language ("HTML"), ${ }^{8}$ or other buried code that is visible to search engines but not to computer users. Using another's trademark in this way may confuse a computer user, at least initially, by creating the false impression that the search results are associated with the trademark owner. In other cases, when a computer user enters a trademark as a search term, the search engine uses the mark as a keyword to prompt the display of an advertisement or a link to the website of an entity other than the mark owner. ${ }^{9}$ Because these practices threaten to divert trade from the trademark owner to others, trademark owners often sue the other supplier and/or the search engine provider, alleging trademark infringement. Contrary to basic intellectual property theory, reviewed herein, and the nuanced misappropriation theory, some courts grant relief. ${ }^{10}$ These courts rely more on the view that one ought not to reap where one has not

court should enjoin the defendant's use of the plaintiff's mark in the defendant's metatags." (emphasis added)).

${ }^{7}$ See, e.g., Brookfield Commc'ns, Inc. v. West Coast Entm't Corp., 174 F.3d 1036, 1066 (9th Cir. 1999) (West Coast preliminarily enjoined from using Brookfield's “moviebuff" trademark as its domain name).

${ }^{8}$ See, e.g., Eli Lilly \& Co. v. Natural Answers, Inc., 233 F.3d 456, 469 (7th Cir. 2000) (Natural Answers, Inc. preliminarily enjoined from using Eli Lilly's trademark "Prozac" in its HTML code).

${ }^{9}$ See, e.g., Site Pro-1, Inc. v. Better Metal, L.L.C., 506 F. Supp. 2d 123, 12324 (E.D.N.Y. 2007). Better Metal paid Yahoo! Inc. to display a sponsored link to the Better Metal website when computer users entered the Site Pro-1 mark as a search term. The district court held that such a use does not qualify as the type of use the trademark statute prohibits. Id. at 127-28.

${ }^{10}$ See infra Part C. 
sown than on proof of consumer confusion about the source of products.

\section{A. MisAPPROPRIATION THEORY}

The simple view of misappropriation theory rests on the premise that persons should not be able to appropriate the benefits of another's investment without a similar investment of their own. Three basic elements reflect this simple view:

(1) Plaintiff has made a substantial investment of time, effort and money into creating the thing misappropriated such that the court can characterize that "thing" as a kind of property right [the creation element].

(2) Defendant had appropriated the "thing" at little or no cost, such that the court can characterize defendant's action as "reaping where it has not sown" [the appropriation element].

(3) Defendant has injured plaintiff by the misappropriation [the injury element]. ${ }^{11}$

Courts routinely cite the Supreme Court's opinion in International News Service v. Associated Press as the basis for what is now, post-Erie Railroad Co. $v$. Tompkins, ${ }^{12}$ the state common law doctrine of misappropriation. ${ }^{13}$

\footnotetext{
"MCCARTHY, supra note $3, \S 10.51$. Some jurisdictions require that the defendant's benefit result from gaining a competitive advantage over the creator. The U.S. Court of Appeals for the Fifth Circuit interpreted Texas law as requiring a modified appropriation element, stating that there must be use of the product created by the plaintiff "in competition with plaintiff, thereby giving the defendant a special competitive advantage because he was burdened with little or none of the expense incurred by plaintiff in the creation of the product." Alcatel USA, Inc. v. DGI Techs., Inc., 166 F.3d 772, 788 (5th Cir. 1999) (citing U.S. Sporting Prods., Inc. v. Johnny Stewart Game Calls, Inc., 865 S.W.2d 214 (Tex. Ct. App. 1993)). The court stated that, unlike other intellectual property laws, "misappropriation law is specifically designed to protect the labor-the so-called 'sweat equity' - that goes into creating a work." Id. (emphasis in original).

${ }_{12} 304$ U.S. 64 (1938) (requiring federal courts to give deference to state courts when interpreting state common law and abandoning the practice of federal courts determining what state common law should be).

${ }^{13}$ See, e.g., McKevitt v. Pallasch, 339 F.3d 530, 534 (7th Cir. 2003); Alcatel, 166 F.3d at 788; Nat'l Basketball Ass'n v. Motorola, Inc., 105 F.3d 841, 843 (2d Cir. 1997); Advance Watch Co., Ltd. v. Kemper Nat'l Ins. Co., 99 F.3d 795, 802 (6th Cir. 1996); Summit Mach. Tool Mfg. Corp. v. Victor CNC Sys., Inc., 7
} 
Revisiting the Supreme Court's opinion, however, reveals a more complex misappropriation doctrine. The International News Service v. Associated Press opinion permitted many people, even competitors, to free-ride on the Associated Press' investment in gathering news. The Associated Press ("AP"), a news gathering organization, distributed news it had collected at great expense to its paying members, primarily newspaper publishers. International News Service ("INS"), through various devices, ${ }^{14}$ took news gathered by AP and distributed it to its own paying members, thereby enabling them to publish the news simultaneously with AP's members. ${ }^{15}$ By taking this news while it was still hot, INS was free-riding on AP's efforts, "endeavoring to reap where it ha[d] not sown." 16 The ensuing injunction did not prevent all freeriding. It prevented only free-riding that "interfere[d] with the normal operation of complainant's legitimate business precisely at the point where the profit is to be reaped, in order to divert a material portion of the profit from those who have earned it to those who have not."17

The Supreme Court specifically recognized that many people, including competitors, could and should be allowed to free-ride on AP's efforts. For instance, the purchaser of a newspaper may spread his or her knowledge of the news gratuitously. ${ }^{18}$ This is an important and allowable free-riding function because society presumably benefits from an informed citizenry. Moreover, competing news organizations may obtain leads from the news gathered by AP and, upon verification, publish their own articles. ${ }^{19}$ Additionally, no one would suppose that AP had the right for all time to report a historic event. ${ }^{20}$

F.3d 1434, 1441 (9th Cir. 1993); Fin. Info., Inc. v. Moody's Investors Serv., Inc., 808 F.2d 204, 208 (2d Cir. 1986); Ehat v. Tanner, 780 F.2d 876, 878 (10th Cir. 1985).

${ }^{14}$ See Int'l News Serv. v. Associated Press, 248 U.S. 215, 229-30 (1918).

${ }^{15} \mathrm{Id}$. at 239.

${ }^{16} \mathrm{Id}$.

${ }^{17} I d$. at 240 (emphasis added).

${ }^{18} \mathrm{Id}$. at 239.

${ }^{19} \mathrm{Id}$. at $242-45$.

${ }^{20}$ Id. at 234. 
The Court determined that AP's right extended only so far as to encourage its newsgathering activity by preventing INS from interfering exactly where a profit was to be made. Accepting INS's argument that the news was abandoned to the public would "render publication profitless, or so little profitable as in effect to cut off the service by rendering the cost prohibitive in comparison with the return."21 The Court balanced the need of the public and competitors to have access to the news with the need for incentives for media companies to invest in newsgathering activities ${ }^{22}$ and thus preserved only AP's lead time advantage.

There are two views of misappropriation. The simple view prohibits one actor from free-riding on the activity of the other. The nuanced view prohibits one actor from free-riding on the activity of the other if doing so would interfere with the incentive to engage in that particular creative activity to the detriment of society at large. Many courts' rulings in Internet initial interest confusion cases reflect the simple view. ${ }^{23}$ Intellectual property theory and trademark law generally reflect the more nuanced view. ${ }^{24}$

\section{B. Trademark and NuanCEd Misappropriation}

Trademark cases generally, and initial interest confusion cases in particular, present a conflict between the need to create incentive for innovation, on one hand, and provide free public access, on the other. The creative activity is trademarking activity, whereby symbols are endowed with information-carrying capacity. A trademark may indicate that the product to which it is affixed

${ }^{21} I d$. at 241.

${ }^{22} \mathrm{~A}$ few misappropriation cases recognize this balancing of incentives and access. See, e.g., U.S. Golf Ass'n v. St. Andrews Sys., Data-Max, Inc., 749 F.2d 1028, 1035 (3d Cir. 1984) ("[T] doctrine can best be viewed as an attempt to provide the necessary incentives to the creators of intellectual property without unnecessarily restricting the public's free access to information."). To resolve this dilemma, the court in U.S. Golf required that the defendant in a misappropriation case be a competitor of the plaintiff. Id. at 1038.

${ }^{23}$ See infra Part C.

${ }^{24}$ See infra Part B. 
comes from a particular source or has certain quality or price characteristics. The Starbucks mark indicates not only that the coffee comes from Starbucks Corporation, but that the coffee is priced higher and brewed stronger than other major brands. At considerable cost, Starbucks provides this information to the public and then protects its investment by ensuring that other coffee shops do not confuse customers by using similar marks. Its trademarking activities include, among other things, signage and labeling, advertising, and discouraging infringers. Through these activities, Starbucks provides considerable benefit to consumers who can be certain that coffee sold with the Starbucks mark affixed will have those characteristics. If Starbucks could not provide that certainty by the exclusive use of the mark as a source indicator, its incentive to invest in trademarking activity would diminish. ${ }^{25}$

Trademark laws reflect society's interest in permitting some others to use an owner's trademark freely. Consumers, for instance, must have access to these marks in order to locate products they desire and reject products they do not like. Consumers use the mark to refer to the products they seek. The Lanham Act also permits suppliers of goods and services to make fair use of another's mark to describe their own goods. ${ }^{26}$ Courts agree that it is good public policy to permit competitors to engage

${ }^{25}$ See, e.g., August Storck K.G. v. Nabisco, Inc., 59 F.3d 616, 619 (7th Cir. 1995) (concluding that, by ignoring the benefits of comparative advertising, the district court had given insufficient consideration to the public interest in promoting competition). Both the FTC and the FDA encourage product comparisons. The FTC believes that consumers gain from comparative advertising, and to make the comparison vivid the Commission "encourages the naming of, or reference to competitors." 16 C.F.R. $§ 14.15$ (b) (2008). A "comparison" to a mystery rival is just puffery; it is not falsifiable and therefore is not informative. Because comparisons must be concrete to be useful, the FDA's regulations implementing the Nutrition Labeling and Education Act of 1990, 21 U.S.C. $\S 301$ (2000), prefer that the object of a nutritional comparison be the market leader (a "comparison" to a product consumers do not recognize is as useless as a comparison to an anonymous rival) or a representative of a nutritional average of the three leading brands. 21 C.F.R. $\S 101.13(\mathrm{j})(1)(\mathrm{ii})(\mathrm{A})$ (2007).

${ }^{26}$ See 15 U.S.C. $\S 1115$ (b)(4) (2000 \& Supp. 2007). For example, the fact that "Apple" is a trademark of Apple Computers, Inc. does not prevent fruit suppliers from accurately describing their produce as being apples. 
in comparative advertising that identifies competing products by their marks ${ }^{27}$ and to use the original manufacturer's marks on reconditioned or repackaged goods. ${ }^{28}$ The First Amendment protects artists and social commentators who use others' trademarks while expressing their views. ${ }^{29}$ These are all referential uses-uses by consumers, competitors, and artists to refer to the mark owners' goods-rather than proprietary uses-uses by sellers to indicate that the owner of the mark is supplying the goods. ${ }^{30}$

When challenged, these referential uses invoke a balancing test. The potential for consumer confusion and accompanying diminution in incentive to engage in trademarking activity arises in situations where it is unclear whether the use is referential or proprietary. When a seller of tattooing inks describes its selection of inks containing very fine pigments as "micro-colors," does the potential confusion arising from the use of a competitor's Microcolors mark outweigh the benefits from increased competition through the provision of an accurate product description $?^{31}$ When a package of Life Savers butter candies says

\footnotetext{
${ }^{27}$ See, e.g., Moseley v. V Secret Catalogue, Inc., 537 U.S. 418, 431-34 (2003).

${ }^{28}$ For an example, see Champion Spark Plug Co. v. Sanders, 331 U.S. 125, 130 (1947), where Sanders reconditioned and sold used Champion Spark Plugs and labeled them using Champion's trademark:

The result is, of course, that the second-hand dealer gets some advantage from the trade mark. But under the rule of Prestonettes, Inc., v. Coty, [in which the defendant repackaged Coty perfume in smaller bottles], that is wholly permissible so long as the manufacturer is not identified with the inferior qualities of the product resulting from wear and tear or the reconditioning by the dealer. Full disclosure gives the manufacturer all the protection to which he is entitled.
}

${ }^{29}$ See, e.g., Rogers v. Grimaldi, 875 F.2d 994, 999 (2d Cir. 1994) ("We believe that in general the [Lanham] Act should be construed to apply to artistic works only where the public interest in avoiding consumer confusion outweighs the public interest in free expression.").

${ }^{30}$ See David W. Barnes, A New Economics of Trademarks, 5 Nw. J. TECH. \& INTELL. Prop. 22, 28-30 (2006) (distinguishing between referential and proprietary uses of trademarks).

${ }^{31}$ See KP Permanent Make-up, Inc. v. Lasting Impression I, Inc., 543 U.S. 111,122 (2004) (opening the door to the weighing of competing considerations including likelihood of confusion and commercial justification); see also David 
that the candies are "25\% LOWER IN CALORIES THAN WERTHER'S® ORIGINAL* CANDY"32 does this use, on balance, confuse consumers about the source or promote competition? When a seller of reconditioned Titleist golf balls truthfully describes the balls as having been repaired, does the competitive benefit of lower prices for balls of different quality outweigh the diminished returns from investment in the Titleist mark? ? $^{33}$ When an artist uses a Barbie doll in his creative work, does the artistic relevance of the doll outweigh the potential confusion about whether Mattel sponsored the art? ${ }^{34}$ Each of these uses takes advantage of the mark owner's name recognition, but the balancing reflects concern for more than the owner's investment. In the descriptive fair use, comparative fair use, and artistic fair use cases described in this paragraph, the user of another's mark may have been reaping where he has not sown, but the resulting "appropriation" is not necessarily "misappropriation."

\section{INITIAL INTEREST CONFUSION: Simple AND NuANCED MisapPROPRIATION}

The most straightforward Internet initial interest confusion cases arise when a competitor uses another's mark as a keyword to produce pop-up advertising or a sponsored link. As an example, a competitor paid Google to display a link to its website whenever a computer user typed in the GEICO mark of a leading insurance company as a search term. ${ }^{35}$ Any confusion about who sponsored

W. Barnes \& Teresa A. Laky, Classic Fair Use: Confusion about Defenses, 20 SANTA Clara Computer \& HIGH TeCH. L.J. 833, 838 (2004) (discussing balancing test in the classic descriptive fair use context).

${ }^{32}$ August Storck K.G. v. Nabisco, Inc., 59 F.3d 616, 617 (7th Cir. 1995).

${ }^{33}$ Nitro Leisure Prods., L.L.C. v. Acushnet Co., 341 F.3d 1356 (Fed. Cir. 2003) (holding that reconditioner of Titleist golf balls had not infringed on mark owner's rights because the marketing sufficiently dissociated the reconditioned balls from the original manufacturer).

${ }^{34}$ Mattel, Inc. v. Walking Mountain Prods., 353 F.3d 792, 807 (9th Cir. 2003) (holding that, because the Barbie mark accurately described the subject of the artistic work and did not explicitly mislead as to Mattel's sponsorship of the work, the balance favored permitting this referential use).

${ }^{35}$ Gov't Employees Ins. Co. v. Google, Inc., 330 F. Supp. 2d 700, 702 (E.D. Va. 2004). 
the ad or link is immediately dispelled when the computer user clicks on the ad or link. The court held that this use of another's mark can form the basis for a trademark infringement claim. ${ }^{36}$

Courts use a variety of policy justifications for finding infringement in these cases that have nothing to do with competition or consumer confusion, but instead concern questions of free-riding. It is a "violation of the Lanham Act," according to the U.S. Court of Appeals for the Tenth Circuit, to "use[] the goodwill associated with Plaintiffs' trademarks in such a way that consumers might be lured to the [products] from Plaintiffs' competitors." 37 The lack of reference to consumer confusion or competition suggests that it does not matter whether consumers are more satisfied or competition is enhanced as a result of the practice. In these cases, it is enough that the competitor uses the other's investment to get noticed. That is why these trademark infringement cases look more like misappropriation cases.

The impact of that diversion of trade on competition is unclear. Customers may be slightly delayed in finding their preferred website, which would slightly raise consumers' costs of searching for a specific seller. The consumer will, however, almost certainly be offered competitive alternatives as a result of this practice, just as a person seeking Listerine on a drugstore shelf will find the store brand nearby. The existence of competitive alternatives lowers prices and creates greater variety, ultimately benefiting consumers. ${ }^{38}$ The store brand free-rides on the drawing power of the Listerine brand. As long as there is no sustained confusion, ${ }^{39}$ the competitive effect seems positive. Keyword advertising

\footnotetext{
${ }^{36}$ Id. at 705 .

${ }^{37}$ Australian Gold, Inc. v. Hatfield, 436 F.3d 1228, 1239 (10th Cir. 2006).

${ }^{38}$ See ADAm SMiTh, The Wealth OF Nations 112 (1776).

${ }^{39}$ If the website to which the computer user is taken confused consumers by misleading them to think that it is sponsored by the mark owner, that would lead to traditional point-of-sale confusion and be analyzed as a typical infringement case. See, e.g., 777388 Ontario Ltd. v. Lencore Acoustics Corp., 105 F. Supp. 2d 56, 63 (E.D.N.Y. 2000) (demonstrating a situation where metatags led computer user to website with product names confusingly similar to plaintiff's marks).
} 
provides additional information to targeted consumers and reduces their cost of finding desirable products. ${ }^{40}$

Many courts ignore any analysis of competitive effects despite trademark law's goal of decreasing search costs and increasing competition. ${ }^{41}$ The courts do not consider the incentive effects of giving greater trademark protection, but instead tend to focus solely on the unfairness of the appropriation of the other's efforts. The problem is that the defendant is "capitalizing on the trademark holder's goodwill." 42 The courts often conclude that the central issue is whether there was an appropriation of goodwill, regardless of the duration of the consumer's confusion: "That consumers who are misled to [the defendant's] website are only briefly confused is of little or no consequence." 43 These courts decline to examine the scope of rights by balancing incentives and access.

\section{Intellectual Property Theory and Misappropriation}

Current as well as evolving intellectual property theory supports a nuanced view of misappropriation requiring a balancing of incentives and access. Scholars increasingly see copyright and patent law as a means for deciding which external benefits resulting from authors' and inventors' creative efforts should be internalized. ${ }^{44}$ The normative lesson from their work is that the

${ }^{40}$ Barnes \& Laky, supra note 31, stated:

Ultimately, the benefit of protecting mark owners' goodwill is to consumers, who may rely on the qualities and characteristics of the supplier's goods conveyed through the mark and appreciate the advantages of vigorous competition. This lowers prices and increases available alternatives to satisfy consumers' diverse tastes. This reliance reduces consumers' cost of seeking information about goods, including not just reading labels, advertising, and literature, but acquiring experience by buying and rejecting unsuitable goods.

Id. at 838-39 (internal citations omitted).

${ }^{41}$ See Barnes, supra note 30 (discussing the goals of trademark law); Barnes \& Laky, supra note 31 (same).

${ }^{42}$ Australian Gold, 436 F.3d at 1239.

${ }^{43}$ Promatek Indus., Ltd. v. Equitrac Corp. 300 F.3d 808, 812 (7th Cir. 2002).

${ }^{44}$ See Brett M. Frischmann \& Mark A. Lemley, Spillovers, 107 ColUM. L. REV. 257, 265 (2007) (applying externalities theory to copyright and patent law); Jeffrey L. Harrison, A Positive Externalities Approach to Copyright Law: Theory and Application, 13 J. INTELL. PROP. L. 1 (2005) (applying the theory of 
law ought to (1) protect works only when doing so creates more social benefits than costs and (2) incur no greater social cost than necessary to provide incentives to the creator. ${ }^{45}$ This is inherently a balancing process.

Costs and benefits reflect the dual concerns of incentives and access. The social costs of enforcing rights to protect incentives come from higher prices and the exclusion of some consumers from the market (deadweight loss), ${ }^{46}$ as well as the costs of administering an enforcement system. The benefits include the potential for an increased supply of creative works accompanied by any subsequent improvement in societal well-being. Externality theory recognizes a balance between the cost of exclusion and the benefit of the creation. In trademark terms, this theory considers whether there is potential for improving incentives to engage in trademarking activity. Internalizing externalities may provide more return from which to finance information production. On the other hand, permitting external benefits through free access to marks for some uses may translate into increased competition.

Public goods theory has traditionally been the economic foundation for intellectual property. ${ }^{47}$ Public goods theory recognizes that the market for the provision of information is potentially flawed. Increasing access facilitates widespread use of

extemalities to copyright law); Alina Ng, Copyright's Empire: Why the Law Matters, 11 MARQ. INTELL. PROP. L. REV. 337 (2007) (using an externalities approach to develop an institutional and technological analysis of copyright).

${ }^{45}$ Harrison, supra note 44, at 6.

${ }^{46}$ See Stewart E. Sterk, Intellectualizing Property: The Tenuous Connections Between Land and Property, 83 WASH. U. L.Q. 417, 467 (2005). Mr. Sterk notes that:

The owner will typically charge a positive price for the resource even though the marginal cost of distributing another unit is zero, resulting in a deadweight loss. Avoiding this loss serves as a foundation for the doctrinal limitations on copyright protection-durational limits, fair Id. use, and first sale among them.

47 Reference to public goods theory is most common in the legal literature discussing copyright issues, but is also quite familiar to those writing in patent law. For a list of articles using public goods theory in both areas, see Barnes, supra note 30 , at 23 n.2 (applying public goods theory to trademark law). 
information at no cost once the information has been produced. Information is non-rivalrous; once a creator has supplied the information, one person's use of the information does not interfere with another person's use. ${ }^{48}$ From an economic perspective, information that can be made available to more users at no additional cost should be made available without charge. ${ }^{49}$

Making information available at zero cost naturally conflicts with creators' incentives. The benefits that creators derive from their own creative work may be insufficient to motivate them. If so, allowing them to exclude others who do not pay a positive price may provide the necessary incentive. ${ }^{50}$ Exclusive rights conflict with free access.

\footnotetext{
${ }^{48}$ See $\mathrm{Ng}$, supra note 44 , at 354.

${ }^{49}$ Trotter Hardy, Not So Different: Tangible, Intangible, Digital, and Analog Works and Their Comparison for Copyright Purposes, 26 U. DAYTON L. REV. 211 (2001), cautioned that there are varying degrees of publicness that should be considered in policy analysis. He summarized the economic perspective as
} follows:

This view, that information is a public good whereas tangible things are not, informs a great deal of thinking about intellectual property. And it leads to the view that this very difference has important public policy consequences, more or less along these lines: Congress should keep firmly in mind three facts. (1) Information is a public good. (2) Every additional form of intellectual property protection, every increase in the scope or number of intellectual property rights, is a restriction on information sharing. (3) Because the marginal cost of such sharing is zero, the right price for that additional customer should be zero, whereas any additional intellectual property protections imply a non-zero price and therefore serve to prevent the socially desirable outcome. In short, many commentators urge us to remember that because information is a public good, Congress should keep the legal restrictions on information-the intellectual property laws-as narrow as possible.

Id. at 225 .

${ }^{50}$ Economists characterize the conflict between access at zero cost and exclusive right to encourage creativity as a conflict between short-term and long-term concerns, static and dynamic efficiency. See, e.g., Brett M. Frischmann, An Economic Theory of Infrastructure and Commons Management, 89 MiNN. L. REV. 917, 947 (2005) (comparing static and dynamic efficiency and concluding: "Taken together, these two perspectives-static and dynamic efficiency-yield a complicated economic puzzle in terms of maximizing social welfare. As a policy matter, it may be necessary to strike a balance between 
These concerns apply to copyright, patent, and trademark law, all of which provide incentives to create and innovate and facilitate public access to information. Trademarks contain information about product source and characteristics. Consumers obtain external benefits when they use the mark to search for goods. Competitors who compare or describe their goods using competitors' marks and social commentators who express themselves using others' marks also gain external benefits. These uses are non-rivalrous. Consumers, competitors, and social commentators can all use source indicators for some referential purposes without interfering with each other's use. Externality theory and public goods theory coincide with a nuanced analysis of misappropriation theory in requiring a balancing of access and exclusive rights.

\section{E. A Balancing Approach to INTERNET INITIAL INTEREST CONFUSION}

A balancing approach to Internet initial interest confusion would consider the incentives, search costs, and competitive effects of expanding exclusive rights. ${ }^{51}$ Consider the incentive effects first. Generally, increased return on investment prompts increased creativity. The makers of "Nutrasweet" brand sweeteners have an additional incentive to invest in the renown of their mark if they can license use of that mark to makers of baked goods containing their product. But incentives to produce more information are not likely to increase by prohibiting keywordprompted advertising. The only way prohibiting this activity would generate investment is if GEICO were willing to license its trademark to the companies currently utilizing the keyword-

opening access to reap static efficiency gains and restricting access to reap dynamic efficiency gains.").

${ }^{51}$ The very idea of trademarks is that they "lower consumer search costs and encourage higher quality production by discouraging free-riders." Union Nat'l Bank of Tex., Laredo, Tex. v. Union Nat'l Bank of Tex., Austin, Tex., 909 F.2d 839, 844 (5th Cir. 1990); see also Park 'N Fly, Inc. v. Dollar Park \& Fly, Inc., 469 U.S. 189, 193 (1985); Enter. Rent-A-Car Co. v. Advantage Rent-A-Car, Inc., 330 F.3d 1333, 1339 (Fed. Cir. 2003) ("To protect trade-marks . . is to promote competition and is sound public policy."). 
prompted advertising when a consumer searches using the GEICO mark. GEICO is, however, unlikely to license its competitor, Allstate, to use the GEICO gecko for Allstate advertisements. Trademark owners are unlikely to license their marks to competitors for any purpose, so there will be no new revenue from that source. Trademark owners might prevent consumers from being diverted to products they would prefer more, and sell more of their products simply because consumers do not know about more or equally desirable alternatives, but that hardly seems like a revenue stream worth protecting.

By contrast, keyword advertising is likely to decrease search costs. A consumer shopping for auto insurance will benefit from entering GEICO as a search term and being informed of Allstate's competitive rates. Costs of finding a particular supplier such as GEICO may be raised slightly because of the clutter of sponsored ads on the search engine's search results page or the need to click out of a sponsored link improperly chosen. Keyword advertising, however, reduces the cost of finding alternative sources of goods and services that might have a better mix of characteristics and prices, and thus leads to increased competition. On balance, keyword advertising appears to aid consumers.

Keyword advertising is also likely to increase competition. Knowing that consumers are likely to compare Allstate and GEICO rates due to keyword advertising, GEICO has an incentive to compete more fiercely for those consumers. To do this, GEICO may lower its prices or provide additional services. Protecting goodwill protects competition if it increases the production of information about product source and characteristics. ${ }^{52}$ But in the area of Internet initial interest confusion, competition is unlikely to be increased by expanding exclusive rights. Any increase in

\footnotetext{
${ }^{52}$ Barnes \& Laky, supra note 31, stated: Protecting goodwill also promotes competition. A new entrant to a market can use their own distinctive marks to establish brand recognition as well as a reputation for providing goods with reliable qualities and characteristics. By informing consumers about alternatives, new entrants use marks and establish goodwill to compete against existing suppliers to satisfy consumer demands.
}

Id. at 838 . 
revenues to the trademark owner in this circumstance results directly from reduced competition. Competition is more likely to be increased by reducing search costs and increasing the availability of competitive alternatives. These can both be accomplished by allowing competitors to use others' trademarks to create sponsored links or Internet advertising when the only result is readily dispelled initial interest confusion. A nuanced interpretation of the misappropriation doctrine supports this result.

\section{CONCLUSION}

The nuanced version of the Supreme Court's misappropriation doctrine better furthers the goals of intellectual property generally and trademark law in particular. This interpretation of misappropriation theory balances incentive creation with free access and leads to trademark law tailored to encourage both trademarking activity and competition. The nuanced approach to the misappropriation doctrine and both traditional and evolving theoretical approaches to intellectual property law suggest that Internet keyword advertising, on balance, reduces search costs and improves competition without interfering with incentives to engage in trademarking activity. 